\title{
Outcome of pyometra in female dogs and predictors of peritonitis and prolonged postoperative hospitalization in surgically treated cases
}

Supranee Jitpean ${ }^{1 *}$, Bodil Ström-Holst ${ }^{1}$, Ulf Emanuelson ${ }^{1}$, Odd V Höglund ${ }^{1}$, Ann Pettersson ${ }^{1}$, Caroline Alneryd-Bull ${ }^{2}$ and Ragnvi Hagman'

\begin{abstract}
Background: One of the most common diseases in intact bitches is pyometra- a potentially life-threatening disease associated with a variety of clinical and laboratory findings. The aims of the present study were to describe complications of the disease and to investigate clinically useful indicators associated with peritonitis and/or prolonged postoperative hospitalization.

Results: A retrospective study was performed using records from 356 bitches diagnosed with pyometra during the years 2006-2007 at the University Animal Hospital, Swedish University of Agricultural Sciences, Uppsala, Sweden. Of the 356 bitches, 315 were surgically treated by ovariohysterectomy, 9 were medically treated and 32 were euthanized without treatment. In the surgically treated bitches, univariable associations between clinical and laboratory data, risk for prolonged hospitalization ( $\geq 3$ days) and/or signs of peritonitis, were analyzed by Chi-square and Fisher's exact test. Logistic regression models were used to assess multivariable associations.

The most common complication observed in surgically treated bitches was peritonitis (40 bitches), followed by urinary tract infection (19 bitches), wound infection (8 bitches), uveitis (6 bitches), and cardiac arrhythmia (5 bitches). Leucopenia and fever/hypothermia were associated with increased risk for peritonitis (18-fold and three-fold, respectively). Moderate to severe depression of the general condition, pale mucous membranes and leucopenia were associated with increased risk (seven-fold, three-fold, and over three-point-five-fold, respectively) for prolonged postoperative hospitalization.

Conclusions: Several clinically useful indicators were identified. Leucopenia was the most important marker, associated with 18-fold increased risk for peritonitis and an over three-point-five increased risk for prolonged hospitalization. Fever/hypothermia, depression and pale mucous membranes were associated with increased risk for peritonitis and/or prolonged hospitalization. The results of the present study may be valuable for identifying peritonitis and predicting increased morbidity in surgically treated bitches with pyometra.
\end{abstract}

Keywords: Bitch, Uterine inflammation, Surgical treatment, Hospitalization, Peritonitis, Risk, Outcome, Dogs

\footnotetext{
* Correspondence: supranee.jitpean@slu.se

'Department of Clinical Sciences, Faculty of Veterinary Medicine and Animal

Science, Swedish University of Agricultural Sciences, Box 7054, SE-750 07

Uppsala, Sweden

Full list of author information is available at the end of the article
} 


\section{Background}

One of the most common diseases in intact bitches is pyometra affecting approximately $25 \%$ before 10 years of age [1]. Differences in incidence rates between breeds have been described [2-4]. The diagnosis is based on case history, physical examination, and laboratory analyses, often combined with radiography and/or ultrasonography of the uterus and ovaries. Clinical signs vary depending on severity of disease [5,6]. Leucocytosis, neutrophilia with left shift, anaemia, monocytosis, hypoalbuminemia as well as affected liver or kidney function are common findings [7]. Pyometra has deadly consequences if left untreated and despite modern treatment routines the mortality is $3-4 \%$ [1]. The safest and most effective treatment is ovariohysterectomy (OHE) but purely medical treatment can be used in selected cases [8]. Though OHE is a routine procedure, anesthesia and surgery in bitches suffering from severe systemic disease or/and organ malfunctions may be hazardous [9]. The majority of bitches with pyometra suffer from systemic inflammatory response syndrome, which previously has been associated with increased hospitalization and mortality rates [10]. It is important, but clinically difficult, to predict outcome which is why indicators for survival, complications and morbidity are wanted. Prognosis or mortality prediction by investigating different physical status and laboratory parameters is currently in demand in both human and veterinary medicine. Guidelines for performing anesthesia and assessing anesthetic risk based on different criteria are also being developed [11,12]. Most clinical variables are, however, unspecific which is why current research focuses on identifying clinically valuable biomarkers with high sensitivity and specificity. In diseases with low mortality, such as pyometra, duration of postoperative hospitalization has been used as a measure for morbidity [5,13-18]. The present study explored clinical and laboratory parameters as indicators of morbidity, measured by duration of postoperative hospitalization and/or peritonitis, using analysis of multivariable associations.

Potentially life-threatening complications of pyometra, described after surgery, include sepsis, septic shock, disseminated bacterial infection, peritonitis and hemorrhage [19-21]. Clinical signs such as vomiting, diarrhea, abdominal distention, decreased appetite or abdominal pain may be observed in animals with septic peritonitis $[22,23]$. These signs are, however, commonly encountered in bitches suffering from pyometra with or without peritonitis [24]. For this purpose, researchers have studied biomarkers as indicators of severity of disease and outcome $[13,25]$. However, adding analyses that are not routinely performed in clinical work may be time consuming and the cost benefit must be considered. The value of clinical analyses and variables routinely available such as case history data, clinical signs, physical examination findings or laboratory biomarkers has not yet been fully explored as indicators of outcome after surgical treatment of pyometra.

The aims of the present study were to describe complications of pyometra and to investigate variables that may be useful as indicators of peritonitis and/or prolonged hospitalization after surgical treatment.

\section{Results}

During the years 2006-2007, 356 bitches of 92 different breeds were diagnosed with pyometra. The age range was one to 15 years (mean \pm SD, $9 \pm 1.4$ years). Seventytwo bitches were $>10$ years old. All bitches were diagnosed within 2 months of the previous oestrus. Oestrus prevention by medroxyprogesterone acetate (MPA, the only registered treatment in Sweden) is rare in Sweden, and was only given to one bitch in the study material.

\section{Case history data, physical examination and laboratory findings}

Case history, physical and laboratory examination data from the 356 bitches with pyometra are shown in Table 1.

\section{Treatment alternatives}

In total, 315 bitches were surgically treated by OHE. In 65 surgically treated bitches (21\%), antimicrobial therapy had been administered prior to admission, and in 124 bitches (35\%) antimicrobials were administered postoperatively. Nine bitches were selected for medical treatment. Thirty-two bitches (9\%) were euthanized after diagnosis without treatment.

\section{Mortality}

The total mortality was $10 \%(36 / 356)$ including euthanasia of 32 bitches and postoperative death of four bitches (1\%) (Table 2). Of the bitches that died postoperatively, one died due to splenic rupture, one due to severe peritonitis and two of unknown causes (Table 3). Euthanasia was performed due to concomitant diseases including severe hip dysplasia $(n=1)$, hepatic disease associated with ascites $(n=1)$, long-term polyuria/polydipsia $(n=1)$, several other diseases $(n=2)$, kidney malfunction $(n=1)$, mammary tumors $(n=1)$, multiple neoplasia in esophagus $(n=1)$, or due to pyometra associated with old age of the bitch $(n=24)$. None of the bitches were euthanized because of a poor prognosis of pyometra.

\section{Complications in all pyometra patients}

Complications reported in the 356 bitches with pyometra were peritonitis $(12.4 \%, \mathrm{n}=44)$, urinary tract infection $(5.3 \%, \mathrm{n}=19)$, wound infection $(2.2 \%, \mathrm{n}=8)$, uveitis $(1.7 \%, \mathrm{n}=6)$, cardiac arrhythmia $(1.4 \%, \mathrm{n}=5)$, persistent polyuria/polydipsia $(0.3 \%, \mathrm{n}=1)$, hepatic disease associated with ascites $(0.3 \%, \mathrm{n}=1)$ and kidney malfunction $(0.3 \%, \mathrm{n}=1)$. 
Table 1 Case history, physical and laboratory examination data as recorded in $\mathbf{3 5 6}$ bitches with pyometra

\begin{tabular}{lll}
\hline Variable & $\begin{array}{l}\text { In no of bitches/ } \\
\text { total no of bitches }\end{array}$ & $\begin{array}{l}\text { Proportion of bitches } \\
\text { with respective } \\
\text { with data recorded }\end{array}$ \\
finding (\%)
\end{tabular}

\section{Case history}

Vaginal discharge

237/309

76.7

Anorexia

$193 / 280$

69.0

Depression

225/356

63.0

Polydipsia

$180 / 292$

61.6

Polyuria

$171 / 288$

59.4

Vomiting

$75 / 356$

21.1

Lameness

$56 / 342$

16.4

Diarrhea

$55 / 356$

15.4

Urinary tract infection

$19 / 342$

5.6

Clinical findings

Fever

Dehydration

Abdominal pain on

palpation

Palpable enlarged uterus

Hyperemic mucous

membranes

Pale mucous membranes

Hypothermia

$96 / 301$

31.9

$94 / 356$

26.4

$81 / 356$

$67 / 356$

18.8

$58 / 356$

16.3

$52 / 356$

14.6

$12 / 301$

4.0

Laboratory analyses

Hematology

Anemia

Neutrophilia

$88 / 177$

49.7

Leucocytosis

Monocytosis

Band neutrophils

Toxic neutrophils

Leucopenia

Neutropenia

Monocytopenia

Clinical chemistry

Increased ALP

Increased bile acids

Increased lactate

Increased BUN

Increased creatinine

Hypoglycemia

Hyperglycemia

Normal $=$ Within the reference range for healthy bitches and for laboratory variables at the Clinical chemistry laboratory, University Animal Hospital, Swedish University for Agricultural Sciences, Sweden.

Data listed includes the number of bitches/the total number of bitches with data recorded and proportion (\%) with respective finding.

\section{Complications in surgically treated pyometra cases}

In total, there were specific complications and prolonged postoperative hospitalization of the surgically treated bitches observed in 25\% (78/315) and 19\% (60/ $315)$, respectively. The specific complications observed were peritonitis $(13 \%, 40 / 315)$ including eight bitches with ruptured uterus, urinary tract infection $(6 \%, 19 /$ $315)$, wound infection $(3 \%, 8 / 315)$, uveitis $(2 \%, 6 / 315)$, and cardiac arrhythmias (1\%, 5/315).

\section{Indicators for prolonged postoperative hospitalization and/or peritonitis}

Clinical signs, physical examination findings and laboratory variables that were investigated for possible associations with prolonged hospitalization ( $\geq 3$ days) or peritonitis are shown in Tables 4 and 5 , respectively. These analyses were only performed in surgically treated bitches. The age and weight did not differ significantly between bitches with or without peritonitis or prolonged hospitalization (data not shown). Other variables not shown were not associated with peritonitis and/or prolonged hospitalization. Results of the multivariable analyses are presented in Tables 6 and 7. The Hosmer-Lemeshow goodness-of-fit statistics were not significant ( $\mathrm{p}=0.86$ and $\mathrm{p}=0.71$, respectively) indicating a good fit of the multivariable models. The models explained 30 and $21 \%$ of the variation, as assessed by the generalized $R^{2}$.

\section{Discussion}

Identifying complications in bitches with pyometra is vital for selecting optimal monitoring routines and treatments and for determination of prognosis. In the present study, complications were observed in $25 \%$ of the bitches treated by OHE. Peritonitis was the most common complication and can be life-threatening [26]. Urinary tract infection (UTI) was the second most common complication (6\%). Previously, subclinical UTI with the same bacterial strain as in the uterus has been demonstrated in $25 \%$ of bitches with pyometra [27]. Though subclinical UTI may resolve without intervention after OHE, proteinuria or clinical signs of disease should be monitored to prevent severe renal disease from developing [28]. In the present study, uveitis was diagnosed in six bitches. Uveitis has not previously been associated with pyometra but has been described in dogs and cats suffering from severe bacterial infection [29,30]. Cardiac arrhythmia, as identified in five bitches, could have been induced by endotoxemia or myocardial injury [21,31]. Peritonitis, uveitis and cardiac arrythmias are serious, but treatable, consequences of endotoxemia and sepsis, further supporting the importance for predicting such complications early [32-34].

In the present study, the total mortality including euthanasia was $10 \%$ which is higher than earlier reported [1]. Our previous study included bitches $<10$ years whereas 
Table 2 Total number, mortality, cases diagnosed with peritonitis or that had prolonged hospitalization (numbers and proportions) in bitches with pyometra that were euthanized, treated surgically or medically

\begin{tabular}{lllll}
\hline Bitches & $\mathbf{n}$ & Mortality $\mathbf{n}(\%)$ & Peritonitis n (\%) & Prolonged hospitalization $\mathbf{n}(\%)$ \\
\hline All & 356 & $36(10 \%)$ & $44(12 \%)$ & $60(19 \%)$ \\
Euthanized & 32 & $32(100 \%)$ & $4(12.5 \%)$ & $0(0 \%)$ \\
Surgically treated & 315 & $4(1 \%)$ & $40(13 \%)$ & $60(19 \%)$ \\
Medically treated & 9 & $0(0 \%)$ & $0(0 \%)$ & $0(0 \%)$ \\
\hline
\end{tabular}

the present study incorporated data from bitches of all ages, hence the $20 \%$ that were $>10$ years may contribute to some extent to explain this difference since the owners could be more likely to choose elective euthanasia instead of treatment in an older dog or that has concurrent diseases (which is more likely in older dogs). Four bitches died postoperatively, resulting in a mortality of $1 \%$ after surgery, which is lower than the $5-27 \%$ in previous reports $[19,31,35]$. Surgical treatment of pyometra had thus a very good prognosis, when performed in the selected cases, in our study. Thirty-two (9\%) bitches were euthanized instead of treated due to old age and/or concurrent diseases (such as mammary tumor), all by request of the owner and in agreement with the veterinary surgeon in charge. These bitches were excluded from the analysis of predictors for increased postoperative hospitalization, peritonitis and mortality because they were not surgically treated and their death was not associated with a poor prognosis or severity of pyometra. Age and weight did not differ between the groups (without complications and hospitalization $<3$ days compared to with complications and/or prolonged hospitalization), showing that peritonitis or prolonged hospitalization was not more common in older bitches. This indicates that age by itself is not a risk-factor for surgical treatment of pyometra [9].

Overall, the most common signs of disease, present in $>50 \%$ of the bitches, included vaginal discharge, anorexia, depression, polydipsia, and polyuria (Table 1), reflecting systemic involvement of the disease in the majority of bitches [19,36,37]. Vaginal discharge, which has been associated with more severe disease and is considered a characteristic sign of pyometra [6], was absent in $23 \%$ of the cases. Obscure signs of illness may make the disease more difficult to recognize and supports the need for diagnostic indicators for pyometra. Interestingly, lameness was present in $56(16 \%)$ of the bitches, which has not been reported previously. It is possible that the activated immune response could, for example, trigger arthritis, as has been suggested in humans [38]. Regarding laboratory findings, leucocytosis with neutrophilia and left shift, monocytosis and anaemia were observed in the majority of bitches, as is common in the disease [19,39].

One of 40 bitches with peritonitis died, resulting in a 3\% mortality in pyometra with peritonitis which is comparatively low compared with mortality rates of $50 \%$ previously reported due to uterine rupture [26]. Importantly, none of the bitches with ruptured uterus died. We may speculate that this could depend on the disease being common in Sweden and possible complications recognized earlier compared with in countries where the majority of the bitches are neutered.

All surgically treated bitches were included in the analyses for identifying indicators for peritonitis and/or prolonged postoperative hospitalization. Two bitches were diagnosed with peritonitis postoperatively and since it could have been subclinical at the time of surgery or caused by uterine leakage during surgery, these bitches were included in the peritonitis group when analyzing for indicators. Moderate to severe depression and pale mucous membranes were associated with increased risk of prolonged postoperative hospitalization (Table 6). A striking result was that leucopenia was associated with a three-point-five-fold increased risk of having prolonged hospitalization compared to normal WBC and also an

Table 3 Clinical signs, findings on physical and laboratory examinations and cause of death of the four bitches that died after surgical treatment of pyometra

\begin{tabular}{|c|c|c|c|c|}
\hline Bitch & Case history & Physical status $^{a}$ & Laboratory analyses $^{\mathbf{b}}$ & $\begin{array}{l}\text { Cause of } \\
\text { death }\end{array}$ \\
\hline No. 1 & $\begin{array}{l}\text { Polyuria, polydipsia, bloody vaginal } \\
\text { discharge, mild depression }\end{array}$ & Hypothermia, mild dehydration, CRT 1-2 sec. & Leucocytosis & Unknown \\
\hline No. 2 & Anorexia, severe depression & $\begin{array}{l}\text { Severe dehydration, abdominal pain, hyperemic } \\
\text { mucous membrane, CRT }>2 \mathrm{sec} \text {. }\end{array}$ & & $\begin{array}{l}\text { Severe } \\
\text { peritonitis }\end{array}$ \\
\hline No. 3 & $\begin{array}{l}\text { Anorexia, bloody-purulent vaginal discharge, } \\
\text { mild depression }\end{array}$ & CRT 1-2 sec. & $\begin{array}{l}\text { Anemia, increased ALP, } \\
\text { increased lactate }\end{array}$ & $\begin{array}{l}\text { Ruptured } \\
\text { spleen }\end{array}$ \\
\hline No. 4 & $\begin{array}{l}\text { Vomiting, diarrhea, purulent vaginal } \\
\text { discharge, severe depression }\end{array}$ & & $\begin{array}{l}\text { Leucopenia, increased } \\
\text { ALP }\end{array}$ & Unknown \\
\hline
\end{tabular}

${ }^{\mathrm{a} C R T}=$ Capillary refill time; ${ }^{\mathrm{b}} \mathrm{ALP}=$ Alkaline phosphatase. 
Table 4 Univariable analysis of association between clinical signs, physical examination findings and laboratory data and the risk of prolonged postoperative hospitalization ( $\geq 3$ days) in bitches with pyometra

\begin{tabular}{|c|c|c|c|c|}
\hline Variable $^{a}$ & & $\begin{array}{l}\text { No. of bitches with prolonged } \\
\text { hospitalization/bitches with variable } n(\%)\end{array}$ & Missing data & $\begin{array}{l}\text { p-value (Chi-square } \\
\text { test/Fisher's exact test) }\end{array}$ \\
\hline \multicolumn{5}{|l|}{ Case history } \\
\hline \multirow[t]{2}{*}{ Anorexia } & Yes & $34 / 167(20)$ & 69 & 0.08 \\
\hline & No & 9/79 (11) & & \\
\hline \multirow[t]{2}{*}{ Polyuria } & Yes & 25/151 (16) & 62 & 0.17 \\
\hline & No & $24 / 102(23)$ & & \\
\hline \multirow[t]{2}{*}{ Polydipsia } & Yes & 24/159 (15) & 59 & 0.04 \\
\hline & No & 25/97 (16) & & \\
\hline \multirow[t]{2}{*}{ Vomiting } & Yes & 21/68 (31) & 0 & 0.005 \\
\hline & No & $39 / 247(16)$ & & \\
\hline \multirow[t]{2}{*}{ Diarrhea } & Yes & 13/51 (25) & 0 & 0.2 \\
\hline & No & $47 / 264(18)$ & & \\
\hline \multirow[t]{2}{*}{ Vaginal discharge } & Yes & $44 / 205(21)$ & 42 & 0.5 \\
\hline & No & 12/68 (18) & & \\
\hline \multirow[t]{4}{*}{ Depression } & Normal (brightness) & 12/126 (9) & 0 & $<0.0001$ \\
\hline & Mild & 20/116 (17) & & \\
\hline & Moderate & 15/54 (28) & & \\
\hline & Severe & 13/19 (68) & & \\
\hline \multirow[t]{2}{*}{ Lameness } & Yes & $13 / 48(27)$ & 14 & 0.11 \\
\hline & No & $44 / 253(17)$ & & \\
\hline \multirow[t]{2}{*}{ Urinary tract infection } & Yes & $3 / 19(16)$ & 14 & 0.7 \\
\hline & No & $54 / 282(19)$ & & \\
\hline \multicolumn{5}{|l|}{ Physical examination } \\
\hline \multirow[t]{3}{*}{ Body temperature } & Normal & $31 / 175(18)$ & 50 & 0.4 \\
\hline & Fever & 20/82 (24) & & \\
\hline & Hypothermia & $1 / 8(12)$ & & \\
\hline \multirow[t]{2}{*}{ CRT } & Normal & 25/133 (19) & 165 & 0.11 \\
\hline & Abnormal & $6 / 17(35)$ & & \\
\hline \multirow[t]{4}{*}{ Mucous membranes } & Normal & $35 / 220(16)$ & 0 & 0.01 \\
\hline & Pale & 14/43 (33) & & \\
\hline & Hyperemic & 10/51 (20) & & \\
\hline & Toxic & $1 / 1(100)$ & & \\
\hline \multirow[t]{4}{*}{ Hydration status } & Normal & $37 / 232(16)$ & 0 & 0.004 \\
\hline & Mild & $15 / 67(22)$ & & \\
\hline & Moderate & $7 / 15(47)$ & & \\
\hline & Severe & $1 / 1(100)$ & & \\
\hline \multirow[t]{2}{*}{ Abdominal pain } & Yes & 20/69 (29) & 0 & 0.02 \\
\hline & No & $40 / 246(16)$ & & \\
\hline \multirow[t]{2}{*}{ Palpable uterus } & Yes & 13/59 (22) & 0 & 0.5 \\
\hline & No & $47 / 256(18)$ & & \\
\hline \multirow[t]{3}{*}{ Ophthalmological exam } & Ocular discharge & $56 / 287(19)$ & 0 & 0.48 \\
\hline & Conjunctivitis & 4/22 (18) & & \\
\hline & Uveitis & $0 / 6(0)$ & & \\
\hline
\end{tabular}


Table 4 Univariable analysis of association between clinical signs, physical examination findings and laboratory data and the risk of prolonged postoperative hospitalization $(\geq 3$ days) in bitches with pyometra (Continued)

\begin{tabular}{|c|c|c|c|c|}
\hline \multicolumn{5}{|c|}{ Laboratory analyses } \\
\hline \multirow[t]{3}{*}{ WBC } & Normal & $21 / 90(23)$ & 102 & $<0.0001$ \\
\hline & Leucocytopenia & $7 / 8(87)$ & & \\
\hline & Leucocytosis & 16/115 (14) & & \\
\hline \multirow[t]{3}{*}{ Neutrophils } & Normal & 19/85 (22) & 110 & $<0.0001$ \\
\hline & Neutropenia & $7 / 8(87)$ & & \\
\hline & Neutrophilia & 15/112 (13) & & \\
\hline \multirow[t]{2}{*}{ Band neutrophils } & Normal & $33 / 166(20)$ & 118 & 0.25 \\
\hline & Increased & 9/31 (29) & & \\
\hline \multirow[t]{2}{*}{ Toxic neutrophils } & Yes & 7/21 (33) & 102 & 0.1 \\
\hline & No & 37/192 (19) & & \\
\hline \multirow[t]{3}{*}{ Monocytes } & Normal & 23/90 (26) & 112 & 0.0004 \\
\hline & Monocytopenia & $5 / 7(71)$ & & \\
\hline & Monocytosis & 14/106 (13) & & \\
\hline \multirow[t]{3}{*}{$\mathrm{Hb}$} & Normal & 9/32 (28) & 260 & 0.7 \\
\hline & Low & $5 / 21(24)$ & & \\
\hline & High & $1 / 2(50)$ & & \\
\hline \multirow[t]{2}{*}{$\mathrm{Hct}$} & Normal & 15/85 (18) & 148 & 0.38 \\
\hline & Anemia & 19/82 (23) & & \\
\hline \multirow[t]{3}{*}{ ALP } & Normal & 17/113 (15) & 134 & 0.48 \\
\hline & Decreased & $1 / 4(25)$ & & \\
\hline & Increased & $14 / 64(22)$ & & \\
\hline \multirow[t]{2}{*}{ Creatinine } & Normal & $35 / 209(17)$ & 100 & 0.0009 \\
\hline & Increased & $4 / 6(67)$ & & \\
\hline \multirow[t]{2}{*}{ Bile acids } & Normal & 4/23 (17) & 285 & 0.5 \\
\hline & Increased & 2/7 (29) & & \\
\hline \multirow[t]{2}{*}{ BUN } & Normal & 5/26 (19) & 288 & 0.09 \\
\hline & Uremia & 1/1 (100) & & \\
\hline \multirow[t]{3}{*}{ Glucose } & Normal & 24/137 (17) & 167 & 0.01 \\
\hline & Hypoglycemia & $4 / 6(67)$ & & \\
\hline & Hyperglycemia & $1 / 5(20)$ & & \\
\hline \multirow[t]{2}{*}{ Lactate } & Normal & 4/17 (23) & 296 & 0.03 \\
\hline & Increased & $2 / 2(100)$ & & \\
\hline
\end{tabular}

${ }^{\mathrm{a}}$ Normal $=$ Within the reference range (as indicated below) for healthy bitches and for laboratory variables at the main Clinical chemistry laboratory, University Animal Hospital, Swedish University for Agricultural Sciences, Sweden. CRT = Capillary refill time $(1-2 \mathrm{~s})$, WBC = White Blood Cell Count (5.8-16.0 $\left.\times 10^{9} / \mathrm{L}\right)$, $\mathrm{Hb}=$ Hemoglobin (132-199 g/L), Hct = Hematocrit (38-57\%), ALP = Alkaline phosphatase $(<5.0 \mu \mathrm{kat} / \mathrm{L})$, BUN = Blood urea nitrogen $(2.5-8.5 \mathrm{mmol} / \mathrm{L}), \mathrm{Neutrophils}$ (3.0-11.5 $\left.\times 10^{9} / \mathrm{L}\right)$, Monocytes (0.2-1.4 x10 $\left./ \mathrm{L}\right)$, Creatinine $(40-130 \mu \mathrm{mol} / \mathrm{L})$, Bile acids $(<10 \mu \mathrm{mol} / \mathrm{L})$, Glucose $(4.5-5.8 \mathrm{mmol} / \mathrm{L})$, Lactate levels $(<2.2 \mathrm{mmol} / \mathrm{L})$, Body temperature $\left(38-39.2^{\circ} \mathrm{C}\right)$.

18-fold increased risk of peritonitis. These results make leucopenia the most important clinical biomarker identified. Leucopenia could be caused by endotoxin-induced bone marrow depression in combination with more chronic inflammatory disease and loss of leucocytes to the uterine lumen. Increased mortality has also been demonstrated in animals and humans with leucopenia in other studies
[40-42]. A WBC within the normal reference range was associated with increased risk for prolonged hospitalization and/or peritonitis as compared to leucocytosis. This could possibly reflect a transition from leucocytosis to leucopenia i.e. leucocytosis appearing earlier in the pathogenesis. Not only may the number of leucocytes be decreased in pyometra, but their function (phagocytic capacity and mitogen-driven 
Table 5 Univariable analysis of associations between clinical signs, physical examination findings and laboratory data and presence of peritonitis in bitches with pyometra

\begin{tabular}{|c|c|c|c|c|}
\hline Variable $^{a}$ & & $\begin{array}{l}\text { No of bitches with peritonitis/ } \\
\text { bitches with variable } \mathrm{n}(\%)\end{array}$ & Missing data & $\begin{array}{l}\mathrm{p} \text {-value (Chi-square } \\
\text { test/Fisher's exact test) }\end{array}$ \\
\hline \multicolumn{5}{|l|}{ Case history } \\
\hline \multirow[t]{2}{*}{ Anorexia } & Yes & 22/166 (13) & 70 & 0.05 \\
\hline & No & $4 / 79(5)$ & & \\
\hline \multirow[t]{2}{*}{ Polyuria } & Yes & 17/148 (11) & 65 & 0.34 \\
\hline & No & 16/102 (16) & & \\
\hline \multirow[t]{2}{*}{ Polydipsia } & Yes & 15/154 (10) & 64 & 0.07 \\
\hline & No & 17/97 (17) & & \\
\hline \multirow[t]{2}{*}{ Vomiting } & Yes & $14 / 64(22)$ & 8 & 0.01 \\
\hline & No & $25 / 243(10)$ & & \\
\hline \multirow[t]{2}{*}{ Diarrhea } & Yes & $8 / 51(16)$ & 8 & 0.5 \\
\hline & No & $31 / 256(12)$ & & \\
\hline \multirow[t]{2}{*}{ Vaginal discharge } & Yes & 27/203 (13) & 44 & 0.99 \\
\hline & No & 9/68 (13) & & \\
\hline \multirow[t]{4}{*}{ Depression } & Normal (brightness) & $8 / 119(7)$ & 8 & $<0.0001$ \\
\hline & Mild & $12 / 115(10)$ & & \\
\hline & Moderate & $11 / 54(20)$ & & \\
\hline & Severe & 8/19 (42) & & \\
\hline \multirow[t]{2}{*}{ Lameness } & Yes & $8 / 48(17)$ & 14 & 0.4 \\
\hline & No & $31 / 253(12)$ & & \\
\hline \multirow[t]{2}{*}{ Urinary tract infection } & Yes & $1 / 19(5)$ & 14 & 0.3 \\
\hline & No & $38 / 282(13)$ & & \\
\hline \multicolumn{5}{|l|}{ Physical examination } \\
\hline \multirow[t]{3}{*}{ Body temperature } & Normal & 16/170 (9) & 57 & 0.006 \\
\hline & Fever & 19/81 (23) & & \\
\hline & Hypothermia & 0/7 (0) & & \\
\hline \multirow[t]{2}{*}{ CRT } & Normal & 15/133 (11) & 166 & 0.03 \\
\hline & Abnormal & $5 / 16(31)$ & & \\
\hline \multirow[t]{3}{*}{ Mucous membranes } & Normal & $22 / 213(10)$ & 8 & 0.02 \\
\hline & Pale & 8/42 (19) & & \\
\hline & Hyperemic & $8 / 51(16)$ & & \\
\hline \multirow[t]{4}{*}{ Hydration status } & Normal & 25/224 (11) & 8 & 0.004 \\
\hline & Mild & $8 / 67(12)$ & & \\
\hline & Moderate & 5/15 (33) & & \\
\hline & Severe & $1 / 1(100)$ & & \\
\hline \multirow[t]{2}{*}{ Abdominal pain } & Yes & $14 / 67(21)$ & 8 & 0.02 \\
\hline & No & $25 / 240(10)$ & & \\
\hline \multirow[t]{2}{*}{ Palpable uterus } & Yes & $6 / 58(10)$ & 8 & 0.5 \\
\hline & No & $33 / 249(18)$ & & \\
\hline \multirow[t]{3}{*}{ Ophthalmological exam } & Ocular discharge & $37 / 279(13)$ & 8 & 0.5 \\
\hline & Conjunctivitis & $2 / 22(9)$ & & \\
\hline & Uveitis & $0 / 6(0)$ & & \\
\hline
\end{tabular}


Table 5 Univariable analysis of associations between clinical signs, physical examination findings and laboratory data and presence of peritonitis in bitches with pyometra (Continued)

\begin{tabular}{|c|c|c|c|c|}
\hline \multicolumn{5}{|c|}{ Laboratory analyses } \\
\hline \multirow[t]{3}{*}{ WBC } & Normal & 10/90 (11) & 102 & $<0.0001$ \\
\hline & Leucopenia & $3 / 5(62)$ & & \\
\hline & Leucocytosis & $11 / 115(10)$ & & \\
\hline \multirow[t]{3}{*}{ Neutrophils } & Normal & 9/85 (11) & 110 & $<0.0001$ \\
\hline & Neutropenia & $3 / 5(62)$ & & \\
\hline & Neutrophilia & 10/112 (9) & & \\
\hline \multirow[t]{2}{*}{ Band neutrophils } & Yes & 18/166 (11) & 118 & 0.07 \\
\hline & Increased & 7/31 (23) & & \\
\hline \multirow[t]{2}{*}{ Toxic neutrophils } & Yes & 4/21 (19) & 102 & 0.3 \\
\hline & No & 22/192 (11) & & \\
\hline \multirow[t]{3}{*}{ Monocytes } & Normal & $12 / 90(13)$ & 112 & 0.02 \\
\hline & Monocytopenia & 3/7 (43) & & \\
\hline & Monocytosis & 9/106 (8) & & \\
\hline \multirow[t]{3}{*}{$\mathrm{Hb}$} & Normal & $5 / 32(16)$ & 260 & 0.5 \\
\hline & Dereased & 4/21 (19) & & \\
\hline & Increased & $1 / 2(50)$ & & \\
\hline \multirow[t]{2}{*}{$\mathrm{Hct}$} & Normal & 10/85 (12) & 148 & 0.9 \\
\hline & Anemia & 9/82 (11) & & \\
\hline \multirow[t]{3}{*}{ ALP } & Normal & 14/108 (13) & 141 & 0.48 \\
\hline & Decreased & $0 / 4(0)$ & & \\
\hline & Increased & $5 / 62(8)$ & & \\
\hline \multirow[t]{2}{*}{ Creatinine } & Normal & $21 / 202(10)$ & 107 & 0.01 \\
\hline & Increased & $1 / 5(20)$ & & \\
\hline \multirow[t]{2}{*}{ Bile acid } & Normal & 3/23 (13) & 285 & 0.9 \\
\hline & Increased & 1/7 (14) & & \\
\hline \multirow[t]{2}{*}{ BUN } & Normal & 5/26 (19) & 285 & 0.63 \\
\hline & Uremia & $0 / 1(0)$ & & \\
\hline \multirow[t]{3}{*}{ Glucose } & Normal & 16/133 (12) & 173 & 0.05 \\
\hline & Hypogycemia & $2 / 4(50)$ & & \\
\hline & Hyperglycemia & $0 / 5(0)$ & & \\
\hline \multirow[t]{2}{*}{ Lactate } & Normal & 4/17 (23) & 296 & 0.4 \\
\hline & Increased & $1 / 2(50)$ & & \\
\hline
\end{tabular}

${ }^{a}$ Normal = Within the reference range (as indicated below) for healthy bitches and for laboratory variables at the Clinical chemistry laboratory, University Animal Hospital, Swedish University for Agricultural Sciences, Sweden. CRT = Capillary refill time $(1-2 \mathrm{~s})$, WBC $=$ White Blood Cell Count $\left(5.8-16.0 \times 10^{9} / \mathrm{L}\right)$ $\mathrm{Hb}=$ Hemoglobin (132-199 $\mathrm{g} / \mathrm{L}), \mathrm{Hct}=$ Hematocrit $(38-57 \%), \mathrm{ALP}=$ Alkaline phosphatase $(<5 \mu \mathrm{kat} / \mathrm{L}), \mathrm{BUN}=\mathrm{Blood}$ urea nitrogen $(2.5-8.5 \mathrm{mmol} / \mathrm{L}), \mathrm{Neutrophils}$ $\left(3.0-11.5 \times 10^{9} / \mathrm{L}\right)$, Monocytes $\left(0.2-1.4 \times 10^{9} / \mathrm{L}\right)$, Creatinine $(40-130 \mu \mathrm{mol} / \mathrm{L})$, Bile acids $(<10 \mu \mathrm{mol} / \mathrm{L})$, Glucose $(4.5-5.8 \mathrm{mmol} / \mathrm{L}$,$) , Lactate levels (<2.2 \mathrm{mmol} / \mathrm{L})$, Body temperature $\left(38-39^{\circ} \mathrm{C}\right)$.

lymphocyte proliferation) is also impaired, negatively affecting the combat against infection [43,44]. Bitches with moderately to severely depressed general condition had a seven-fold increased risk for prolonged hospitalization. Pale mucous membranes, which might reflect anemia, were associated with a three-fold increased risk of prolonged hospitalization. In contrast, hyperemic mucous membranes were associated with decreased risk for prolonged hospitalization. Lactate levels, though only analyzed in 19 dogs, were associated with increased risk for prolonged hospitalization, indicating a predictive value.

Other variables than leucopenia were linked with presence of peritonitis. Fever, or hypothermia present in merely a third of the pyometra cases, was associated with a three-fold increased risk of peritonitis indicating a 
Table 6 Multivariable logistic regression model of association between clinical signs, physical examination findings and laboratory data and the risk of prolonged postoperative hospitalization ( $\geq 3$ days) in bitches with pyometra $(\mathrm{n}=184)$

\begin{tabular}{|c|c|c|c|c|}
\hline Variable $^{a}$ & & Estimated coefficient & Odds Ratio ( $95 \%$ confidence interval) & $\mathrm{p}$-value \\
\hline \multirow[t]{2}{*}{ Polydipsiab } & Yes & $-0.83( \pm 0.44)$ & 0.43 & 0.056 \\
\hline & & & $(0.18-1.02)$ & \\
\hline \multirow[t]{2}{*}{ Vomiting $^{\mathrm{b}}$} & Yes & $0.77( \pm 0.46)$ & 2.16 & 0.097 \\
\hline & & & $(0.87-5.38)$ & \\
\hline \multirow[t]{4}{*}{ Depression } & Mild & $1.14( \pm 0.57)$ & 3.14 & 0.008 \\
\hline & & & $(1.02-9.64)$ & \\
\hline & Moderate to severe & $1.91( \pm 0.61)$ & 6.78 & \\
\hline & & & $(2.03-22.59)$ & \\
\hline \multirow[t]{4}{*}{ Mucous membranes } & Pale & $1.13( \pm 1.37)$ & 3.09 & 0.021 \\
\hline & & & $(1.06-8.96)$ & \\
\hline & Hyperemic & $-0.95( \pm 0.64)$ & 0.39 & \\
\hline & & & $(0.11-1.35)$ & \\
\hline \multirow[t]{4}{*}{ WBC } & Leucopenia & $1.26( \pm 1.37)$ & 3.53 & 0.012 \\
\hline & & & $(0.24-51.73)$ & \\
\hline & Leucocytosis & $-1.31( \pm 0.49)$ & 0.27 & \\
\hline & & & $(0.1-0.71)$ & \\
\hline
\end{tabular}

${ }^{a}$ Normal = Within the reference range for healthy bitches and for laboratory variables at the main Clinical chemistry laboratory, University Animal Hospital, Swedish University for Agricultural Sciences, Sweden; WBC = White blood cell count (ref. range $\left.5.8-16 \times 10^{9} / \mathrm{L}\right) ;{ }^{\mathrm{b}}$ The variable is not statistically significant $(p>0.05$ ), but included as a confounder in the model.

prognostic value for this variable. Uterine diameter was not associated with peritonitis or prolonged hospitalization, which would otherwise be plausible since a larger uterus could have indicated more severe local disease.

Some parameters were analyzed only in a few bitches hence missing data is a limitation in our study. Retrospectively collected data may also be less reliable than prospectively collected data. Because the bitches selected for medical treatment were already less severely affected by their disease than those subjected to surgical treatment, the data reported here cannot serve as a comparison of the two treatment methods. The results of the present study will increase the possibilities to predict prognosis and outcome after surgical treatment of pyometra. This will be valuable in early identification of cases with peritonitis and/or increased morbidity (hospitalization), which will in turn aid in treatment selection and thereby possibly also increase survival.

\section{Conclusions}

Complications such as peritonitis, uveitis, urinary tract infection, wound infection and cardiac arrhythmias were observed in bitches with pyometra. Several routine parameters that may be useful as indicators of peritonitis

Table 7 Multivariable logistic regression model of associations between clinical signs, physical examination findings and laboratory data and the presence of peritonitis in bitches with pyometra $(n=158)$

\begin{tabular}{|c|c|c|c|c|}
\hline Variable $^{a}$ & & Estimated coefficient & Odds Ratio (95\% confidence interval) & $\mathrm{p}$-value \\
\hline \multirow[t]{2}{*}{ Polydipsia ${ }^{b}$} & Yes & $-0.91( \pm 0.53)$ & 0.40 & 0.084 \\
\hline & & & $(0.14-1.13)$ & \\
\hline \multirow[t]{2}{*}{ Body temperature } & Fever/hypothermia & $1.19( \pm 0.50)$ & 3.30 & 0.017 \\
\hline & & & $(1.23-8.82)$ & \\
\hline \multirow[t]{4}{*}{ WBC } & Leucopenia & $2.90( \pm 1.20)$ & 18.11 & 0.043 \\
\hline & & & $(1.74-188.92)$ & \\
\hline & Leucocytosis & $-0.10( \pm 0.54)$ & 0.90 & \\
\hline & & & $(0.32-2.56)$ & \\
\hline
\end{tabular}

${ }^{a}$ Normal = Within the reference range for healthy bitches and for laboratory variables at the main Clinical chemistry laboratory, University Animal Hospital, Swedish University for Agricultural Sciences, Sweden; WBC = White blood cell count (ref. range 5.8-16 $\left.\times 10^{9} / \mathrm{L}\right)$; Body temperature $\left(\right.$ ref. range $\left.38-39^{\circ} \mathrm{C}\right) ;{ }^{\circ}$ The variable is not statistically significant $(p>0.05)$, but included as a confounder in the model. 
and/or prolonged hospitalization were identified. Leucopenia was associated with increased risk for peritonitis and prolonged hospitalization making leucopenia the most important biomarker to be aware of clinically. The results of the present study will be clinically valuable for identifying peritonitis in bitches with pyometra and the prediction of prolonged postoperative hospitalization after surgical treatment.

\section{Methods}

\section{Animals}

Only journal data already available was used for the study and ethical approval therefore not necessary to obtain according to Swedish regulations.

A retrospective study was carried out using data records from all bitches diagnosed with pyometra during the years 2006-2007 at the University Animal Hospital (UDS), Swedish University of Agricultural Sciences (SLU), Uppsala, Sweden. Bitches were identified by the diagnostic code for pyometra used in Sweden [26]. The animal hospital's patient records include data such as breed, weight, age, case history, physical examination findings, results of radiographic and/or ultrasonographic examinations, laboratory analyses including hematology and serum biochemistry, treatments, date of dismission and follow-ups at the UDS. The preliminary diagnosis pyometra was based on the results of case history, physical examination and diagnostic imaging. The cases were admitted mainly within 2 months of previous oestrus (in metoestrus), not associated to parturition or pregnancy and all dogs had signs of systemic illness. Ultrasonography or radiography or both were used to demonstrate an enlarged, fluid-filled uterus. The diagnosis pyometra was verified visually during ovariohysterectomy and according to the previous definitions by De Bosschere and others (2001) [45]. Bitches with cystic endometrial hyperplasia, mucometra, hydrometra, hematometra and endometritis were not included. The bitches diagnosed with pyometra were divided into three groups depending on whether they were euthanized, medically or surgically treated. Euthanasia was performed at the request of the owner and in agreement with the veterinary surgeon in charge due to concomitant diseases. Bitches with normal hydration status, unaffected or slightly depressed general condition and with no ovarian or endometrial cysts demonstrated on ultrasonographic examination were selected for medical treatment with aglepristone (Alizin vet ${ }^{\circ}$, Virbac, France) in combination with antimicrobials. The success of the medical treatment was evaluated by ultrasonography and laboratory tests including hematology, total white blood cell counts and differential counts to monitor the treatment response. In this study, all medically treated cases recovered as judged by normal laboratory tests and no uterine or ovarian pathology on diagnostic imaging. Furthermore, data from the surgically treated bitches were analyzed for indicators of preexisting peritonitis or development of postoperative peritonitis or prolonged postoperative hospitalization. Intraocular pressure was measured in all bitches with uveitis.

\section{Variables as indicators of peritonitis and/or prolonged hospitalization}

Variables included in the analyses for indicators of peritonitis and/or prolonged postoperative hospitalization were as follows: appetite, body temperature, depression, mucous membrane appearance, hydration status, capillary refill time (CRT), polyuria, polydipsia, vomiting, diarrhea, vaginal discharge, lameness, urinary tract infection, presence of abdominal pain on palpation, palpable enlarged uterus and all other pathological findings noted when performing a complete physical examination. The following laboratory variables were included in the analyses: total white blood cell count (WBC) with differential counts and morphology, hemoglobin $(\mathrm{Hb})$, hematocrit $(\mathrm{Hct})$, alkaline phosphatase (ALP), creatinine, bile acids, blood urea nitrogen (BUN), glucose and lactate concentrations. Additionally, antimicrobial administration, ligation material used during surgery, presence of peritonitis at surgery, administered drugs (anesthetic agents, analgesics, i.v. fluid therapy), duration of postoperative hospitalization and uterine diameter (as determined by ultrasonography or macroscopically during surgery) were integrated in the analyses. The study defined abnormality of hematology and blood chemistry by using the reference ranges at the main clinical chemistry laboratory, UDS, SLU. Case history, laboratory and clinical examination variables recorded before surgery were used in the analysis.

\section{Determination of prolonged hospitalization and peritonitis}

In general, bitches subjected to OHE due to pyometra at UDS are hospitalized 1-2 days. Prolonged postoperative hospitalization (defined as $\geq 3$ days) is only warranted if specific complications occur, if the general condition is depressed and the bitch requires additional veterinary care and monitoring (considered as an unspecific complication). Peritonitis was identified by free fluid and/or hyperechoic fat tissue (steatitis) detected on ultrasonographic examination of the abdomen or decreased serosal detail observed on radiographic examination (as a consequence of steatitis and/or intra-abdominal fluid). Macroscopically peritonitis was identified visually by fibrin or other signs of inflammation on the surface of the abdominal structures or pus present in the abdominal cavity or by positive bacterial culture from the abdominal fluid. In two bitches, peritonitis was diagnosed the day after surgery. 


\section{Statistical analysis}

Univariable associations between potential risk factors within case history, physical examination and laboratory data and the outcomes prolonged hospitalization and signs of peritonitis, respectively, were analyzed by Chi-Square test and Fisher's exact test. Multivariable associations between these potential risk factors and the outcomes were analyzed by logistic regression models. All variables with a $\mathrm{p}$-value $\leq 0.20$ in the univariable analyses were considered as potential predictor variables. Categorical predictor variables were introduced in the models coded as dummy variables. Collinearity between potential predictor variables were assessed by variance inflation factors (VIF) above 10 [46] in which case the variable with a) least missing values or b) providing the best model fit was retained. Modeling was done manually by backward elimination of nonsignificant $(p>0.05)$ variables. At each step, previously eliminated variables were tested for reentry. Confounding was assessed by comparing the change in estimated coefficients when variables were excluded from the model, and were considered present if a coefficient changed $>20 \%$. The fit of the final multivariable model was assessed with a Hosmer-Lemeshow goodness-of-fit test [47] and the coefficient of determination was assessed with a generalized $R^{2}$ as suggested by Nagelkerke (1991) [48]. All statistical analyses were performed using SAS (version 9.3, SAS Institute Inc., Cary, NC, USA).

\section{Competing interests}

None of the authors have any conflict of interest to declare.

\section{Authors' contributions}

SJ drafted the manuscript. CAB, SJ, RH, AP, and $\mathrm{OH}$ provided data and managed the data records. UE performed statistical analyses. RH, AP, BSH, $\mathrm{CAB}, \mathrm{UE}$ and $\mathrm{OH}$ reviewed and commented the manuscript during its preparation. All authors read and approved the final manuscript.

\section{Acknowledgements}

The University Animal Hospital kindly allowed us access to the database. Financial support was obtained from The Agria Pet Insurance's and the Swedish Kennel Club's Research Foundation and The Thure F. and Karin Forsberg's Foundation.

\section{Author details}

'Department of Clinical Sciences, Faculty of Veterinary Medicine and Animal Science, Swedish University of Agricultural Sciences, Box 7054, SE-750 07 Uppsala, Sweden. 'Djursjukhuset Malmö, Cypressvägen 11, Box 9090, 20039 Malmö, Sweden.

Received: 14 March 2013 Accepted: 3 January 2014

Published: 7 January 2014

\section{References}

1. Egenvall A, Hagman R, Bonnett BN, Hedhammar A, Olson P, Lagerstedt AS: Breed risk of pyometra in insured dogs in Sweden. J Vet Intern Med 2001, 15(6):530-538.

2. Jitpean S, Hagman R, Holst BS, Hoglund OV, Pettersson A, Egenvall A: Breed Variations in the Incidence of Pyometra and Mammary Tumours in Swedish Dogs. Reprod Domest Anim 2012, 47:347-350.

3. Niskanen M, Thrusfield MV: Associations between age, parity, hormonal therapy and breed, and pyometra in Finnish dogs. Vet Rec 1998, 143(18):493-498
4. Jayaprakash R, Sathiamoorthy T, Sureshkumar R: Incidence of pyometra in bitches: a retrospective study of 249 cases. TANUVAS 2007, 3(3):164-165.

5. Fransson BA, Karlstam E, Bergstrom A, Lagerstedt AS, Park JS, Evans MA, Ragle CA: C-reactive protein in the differentiation of pyometra from cystic endometrial hyperplasia/mucometra in dogs. J Am Anim Hosp Assoc 2004, 40(5):391-399.

6. Hardy RM, Osborne CA: Canine pyometra: pathophysiology, diagnosis and treatment of uterine and extra-uterine lesions. J Am Anim Hosp Assoc 1974, 10(3):245-268.

7. Sato J, Yasuda J, Muraoka N, Sato R, Tomizawa N, Miyake Y, Okada K, Naito Y: High level of serum alkaline phosphatase activity and isoenzymes in cases of canine pyometra. J JPN Vet Med Assoc 2002, 55(6):367-370.

8. Trasch K, Wehrend A, Bostedt H: Follow-up examinations of bitches after conservative treatment of pyometra with the antigestagen aglepristone. J Vet Med A 2003, 50(7):375-379.

9. Bille C, Auvigne V, Libermann S, Bomassi E, Durieux P, Rattez E: Risk of anaesthetic mortality in dogs and cats: an observational cohort study of 3546 cases. Vet Anaesth Analg 2012, 39(1):59-68.

10. Fransson BA, Lagerstedt AS, Bergstrom A, Hagman R, Park JS, Chew BP, Evans MA, Ragle CA: C-reactive protein, tumor necrosis factor alpha, and interleukin-6 in dogs with pyometra and SIRS. J Vet Emerg Crit Car 2007, 17(4):373-381.

11. Vincent JL, Moreno R, Takala J, Willatts S, DeMendonca A, Bruining H, Reinhart CK, Suter PM, Thijs LG: The SOFA (sepsis-related organ failure assessment) score to describe organ dysfunction/failure. Intens Care Med 1996, 22(7):707-710.

12. Knaus WA, Draper EA, Wagner DP, Zimmerman JE: APACHE-II- a severity of disease classification-system. Crit Care Med 1985, 13(10):818-829.

13. Hagman R, Kindahl H, Fransson BA, Bergstrom A, Holst BS, Lagerstedt AS: Differentiation between pyometra and cystic endometrial hyperplasia/ mucometra in bitches by prostaglandin F2alpha metabolite analysis. Theriogenology 2006, 66(2):198-206.

14. Zhang X-C, Zhang Z-D, Huang D-S: Prediction of Length of ICU Stay Using Data-mining Techniques: an Example of Old Critically III Postoperative Gastric Cancer Patients. Asian Pac J Cancer P 2012, 13(1):97-101.

15. Bo M, Cacello E, Ghiggia F, Corsinovi L, Bosco F: Predictive factors of clinical outcome in older surgical patients. Arch Gerontol Geriat 2007, 44(3):215-224.

16. Lee PS, Drager LR, Stossel TP, Moore FD, Rogers SO: Relationship of plasma gelsolin levels to outcomes in critically ill surgical patients. Ann Surg 2006, 243(3):399-403.

17. Hein OV, Birnbaum J, Wernecke K, England M, Konertz W, Spies C: Prolonged intensive care unit stay in cardiac surgery: Risk factors and long-term-survival. Ann Thorac Surg 2006, 81(3):880-885.

18. Higgins TL, McGee WT, Steingrub JS, Rapoport J, Lemeshow S, Teres D: Early indicators of prolonged intensive care unit stay: Impact of illness severity, physician staffing, and pre-intensive care unit length of stay. Crit Care Med 2003, 31(1):45-51.

19. Wheaton LG, Johnson AL, Parker AJ, Kneller SK: Results and complications of surgical-treatment of pyometra- a review of 80 cases. J Am Anim Hosp Assoc 1989, 25(5):563-568.

20. Musal B, Tuna B: Surgical therapy of complicated uterine stump pyometra in five bitches: a case report. Vet Med-Czech 2005, 50(12):558-562.

21. Marretta SM, Matthiesen DT, Nichols R: Pyometra and its complications. Probl Vet Med 1989, 1(1):50-62.

22. Dye T: The acute abdomen: a surgeon's approach to diagnosis and treatment. Clin Tech Small An P 2003, 18(1):53-65.

23. Franks JN, Howe LM: Evaluating and managing acute abdomen. Vet Med 2000, 95(1):56-58. 60-65, 67-69.

24. Hagman R, Reezigt BJ, Ledin HB, Karlstam E: Blood lactate levels in 31 female dogs with pyometra. Acta Vet Scand 2009, 51(2):9.

25. Gebhardt C, Hirschberger J, Rau S, Arndt G, Krainer K, Schweigert FJ, Brunnberg L, Kaspers B, Kohn B: Use of C-reactive protein to predict outcome in dogs with systemic inflammatory response syndrome or sepsis. J Vet Emerg Crit Car 2009, 19(5):450-458.

26. Oelzner J, Munnich A: Diagnostic and therapeutic aspects of the pyometra-endometritis complex in dogs. Tierarztl Prax 1997, 25(3):249-253.

27. Sandholm M, Vasenius $H$, Kivisto AK: Pathogenesis of canine pyometra. J Am Vet Med Assoc 1975, 167(11):1006-1010. 
28. Heiene R, Kristiansen V, Teige J, Jansen JH: Renal histomorphology in dogs with pyometra and control dogs, and long term clinical outcome with respect to signs of kidney disease. Acta Vet Scand 2007, 49:13.

29. Pumphrey SA, Pirie CG, Rozanski EA: Uveitis associated with septic peritonitis in a cat. J Vet Emerg Crit Car 2011, 21(3):279-284.

30. Dziezyc J: Canine systemic bacterial infections. Vet Clin N Am-Small 2000, 30(5):1103-1117.

31. Hagman R, Lagerstedt AS, Fransson BA, Bergstrom A, Haggstrom J: Cardiac troponin I levels in canine pyometra. Acta Vet Scand 2007, 49:6.

32. Stone EA, Littman MP, Robertson $J$, Bovee KC: Renal dysfuction in dogs with pyometra. J Am Vet Med Assoc 1988, 193(4):457-464.

33. Conti-Patara A, Caldeira JA, De Mattos-Junior E, De Carvalho HS, Reinoldes A, Pedron BG, Patara M, Francisco Talib MS, Faustino M, De Oliveira CM, et al: Changes in tissue perfusion parameters in dogs with severe sepsis/ septic shock in response to goal-directed hemodynamic optimization at admission to ICU and the relation to outcome. J Vet Emerg Crit Car 2012, 22(4):409-418

34. Okano S, Tagawa M, Takase K: Relationship of the blood endotoxin concentration and prognosis in dogs with pyometra. J Vet Med Sci 1998 60(11):1265-1267.

35. Kuplulu S, Vural MR, Demirel A, Polat M, Akcay A: The comparative evaluation of serum biochemical, haematological, bacteriological and clinical findings of dead and recovered bitches with pyometra in the postoperative process. Acta Vet-Beograd 2009, 59(2-3):193-204.

36. Dow C: The cystic hyperplasia-pyometra complex in the bitch. Vet Rec 1957, 69:1409-1415.

37. Borresen B: Pyometra in the dog- a pathophysiological investigation. II. Anamnestic, clinical and reproductive aspects. Nord Vet Med 1979, 31 (6):251-257.

38. Aslan M, Kasapcopur O, Yasar H, Polat E, Saribas S, Cakan H, Dirican A, Torun MM, Arisoy N, Kocazeybek B: Do infections trigger juvenile idiopathic arthritis? Rheumatol Int 2011, 31(2):215-220.

39. Fransson B, Lagerstedt AS, Hellmen E, Jonsson P: Bacteriological findings, blood chemistry profile and plasma endotoxin levels in bitches with pyometra or other uterine diseases. J Vet Med A 1997, 44(7):417-426.

40. Van Israel N, Kirby BM, Munro EAC: Septic peritonitis secondary to unilateral pyometra and ovarian bursal abscessation in a dog. J Small Anim Pract 2002, 43(10):452-455.

41. Adib-Conquy $\mathrm{M}$, Cavaillon J-M: Compensatory anti-inflammatory response syndrome. Thromb Haemost 2009, 101(1):36-47.

42. Kiehl MG, Ostermann $H$, Meyer J, Kienast J: Nitric oxide synthase inhibition by L-NAME in leukocytopenic patients with severe septic shock. Intens Care Med 1997, 23(5):561-566.

43. Faldyna M, Laznicka A, Toman M: Immunosuppression in bitches with pyometra. J Small Anim Pract 2001, 42(1):5-10

44. Holst BS, Gustavsson MH, Lilliehook I, Morrison D, Johannisson A: Leucocyte phagocytosis during the luteal phase in bitches. Vet Immunol Immunopathol 2013, 153(1-2):77-82.

45. De Bosschere H, Ducatelle R, Vermeirsch H, Van den Broeck W, Coryn M: Cystic endometrial hyperplasia-pyometra complex in the bitch: Should the two entities be disconnected. Theriogenology 2001, 55(7):1509-1519.

46. Dohoo I, Martin W, Stryhn H: Veterinary Epidemiologic Research. 2nd edition. Charlottetown: VER Inc; 2009

47. Hosmer DW Jr, Lemeshow S: Applied Logistic Regression. 2nd edition. New York: John Wiley \& Sons; 2000.

48. Nagelkerke NJD: A note on a general definition of the coefficient of determination. Biometrika 1991, 78(3):691-692.

doi:10.1186/1746-6148-10-6

Cite this article as: Jitpean et al:: Outcome of pyometra in female dogs and predictors of peritonitis and prolonged postoperative hospitalization in surgically treated cases. BMC Veterinary Research 2014 10:6.

\section{Submit your next manuscript to BioMed Central and take full advantage of:}

- Convenient online submission

- Thorough peer review

- No space constraints or color figure charges

- Immediate publication on acceptance

- Inclusion in PubMed, CAS, Scopus and Google Scholar

- Research which is freely available for redistribution

Submit your manuscript at www.biomedcentral.com/submit 